\title{
Reconstruction of Paleoceanography Significance in the Western Pacific and Atlantic Oceans during the Neogene Based on Calcareous Nannofossil Productivity and Size Variations, Related to the Global Tectonic Events
}

\author{
Santi Dwi Pratiwi, Tokiyuki Sato \\ Department of Geosciences, Geotechnology and Materials Engineering for Resources, Akita University, Akita, \\ Japan \\ Email: rhabdosphaera@gmail.com,toki@gipc.akita_u.ac.jp
}

Received 13 July 2016; accepted 27 August 2016; published 30 August 2016

Copyright (C) 2016 by authors and Scientific Research Publishing Inc.

This work is licensed under the Creative Commons Attribution International License (CC BY).

http://creativecommons.org/licenses/by/4.0/

(c) (i) Open Access

\begin{abstract}
We investigated the calcareous nannofossils in the western Pacific and Bahama Bank of Caribbean Sea to reconstruct the paleoceanography and correlate with the global events. The absolute abundant of coccolith (number/g) are gradually increased from NN6 throughout NN19 Zone, while the relative abundance of Discoaster is decreased at Sites 782 in the western Pacific Ocean. The changes of the modal and maximum size of Reticulofenestra which are strongly reflected the collapse of sea surface stability, show four times in 8.8 Ma, 6.4 Ma, 5.4 Ma and 3.75 Ma at Site 782. On the basis of relationship between the changes of maximum sizes of Reticulofenestra and nutrient condition, these eutrophication events are clearly traceable to the western Pacific, Bahama Bank, northwestern Pacific Ocean and to the Indian Ocean. Two paleoceanographic events found in 8.8 Ma and 3.75 Ma are interpreted as change to high nutrient condition resulted in the intensification of Asian Monsoon and closure of Panama Isthmus.
\end{abstract}

\section{Keywords}

Calcareous Nannofossils, Paleoceanography, Coccolith (Number/g), Discoaster, Reticulofenestra, Eutrophication Events, Paleoceanographic Events 


\section{Introduction}

Coccolithophorids, which live in photic zone of world Ocean, are considered to be sensitive to changes in sea surface temperature and nutrient conditions. As these reasons, nannofossils, fossil of Coccolithophorids, are useful not only for biostratigraphy but also for paleoceanographical reconstruction of Mesozoic and Cenozoic ages.

Although the coccolithophorids live in upper photic zone in recent ocean, a few species such as Florisphaera profunda, present in lower photic zone in recent stable Ocean [1] [2]. The ecological characteristic of Florisphaera profunda is applicable to reconstruction of paleoceanographic conditions on stability and nutrient conditions of surface Ocean. However, as the occurrence of Florisphaera profunda is limited in the interval of Pliocene to Quaternary, it's difficult to apply to reconstruct the stability of surface Ocean to the Neogene sequence based on the ecology of Florisphaera profunda.

Scientist focused on paleoecology of discoasters. Discoaster had been interpreted as warm water species based on limited distribution in lower latitude region [3] [4]. Aubry [5] interpreted the discoasters as lower photic zone species based on their distributions. Stoll et al. [6] interpreted that Discoaster lived in lower photic zone based on $\mathrm{Sr}$ of discoasters in the Paleogene sequence. This indicates that the discoasters are useful tool for reconstruction of paleoceanographic conditions such as ocean surface stability.

On the other hand, Takahashi and Okada [7] showed that coccolith size is a good tool for indicator of sea surface nutrient conditions. Based on these research results, recently, Sato and Chiyonobu [8] reconstruct the history of surface ocean stability based on coccolith size and Discoaster abundance. Farida et al. [9] and Imai et al. [10] also discussed the Neogene paleoceanography of Pacific Ocean based on Discoaster abundance, nannofossil productivity and Reticulofenestra size. However, the problems for interpretation on the cause of these paleoceanography changes and the relationship between other areas are still remained.

Our purpose of this study is focused to reconstruction of the Neogene paleoceanography of western Pacific and Caribbean Sea based on Discoaster abundance and Reticulofenestra size variabilities. On the basis of comparison of our results with those of Indian Ocean (Young, 1990) [11], and northwestern Pacific Ocean (Imai et al., 2015) [10], we discuss the paleoceanographic events through the Neogene, and interpret the cause of the events based on the correlation to global tectonic and climatic events.

\section{Location and Study Area}

Leg 125, Site 782 Hole A in the Izu-Bonin forearc of the western Pacific Ocean, and Leg 166, Site 1007, Hole B and Hole C in the Bahama Bank of Caribbean Sea are analyzed for this study (Figure 1). Site $782\left(30^{\circ} 51.66\right.$ 'N, $141^{\circ} 18.85^{\prime} \mathrm{E}$ ) situated in $2958.9 \mathrm{~m}$ of water depth is influenced by the Kuroshio Current. The Kuroshio Current is the major western boundary current of the North Pacific Ocean gyre and is formed at the western end of the North Equatorial Current (NEC).

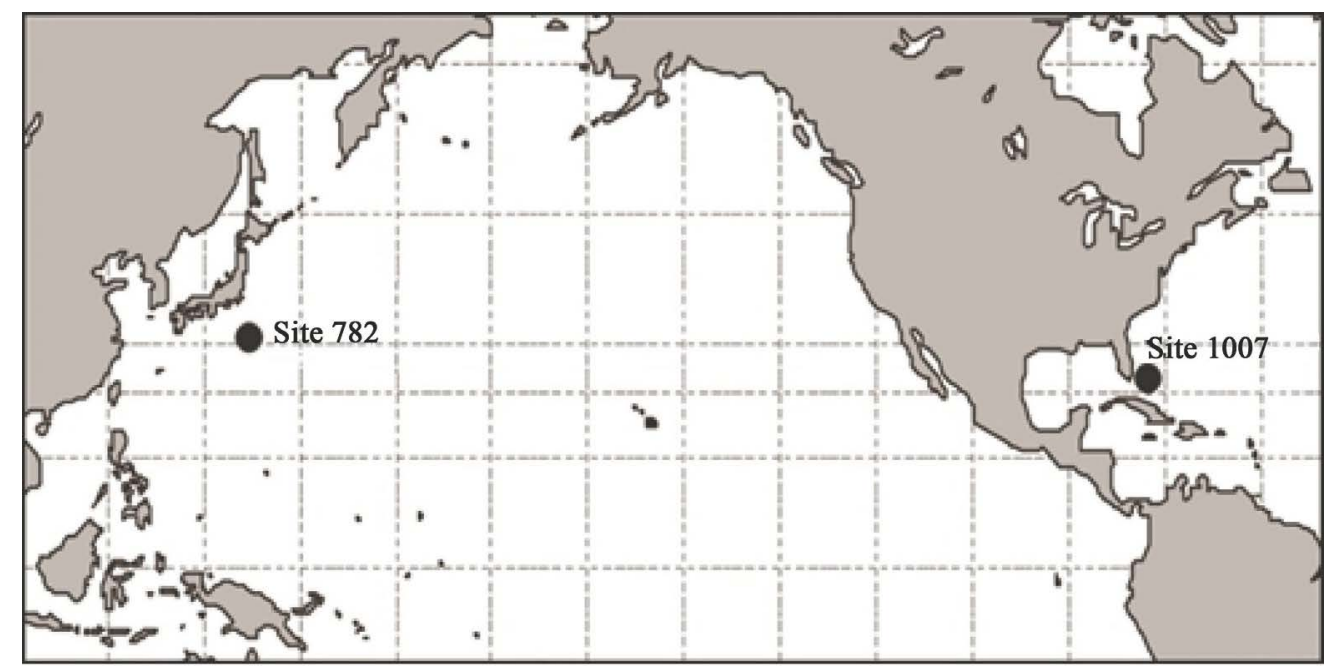

Figure 1. Map showing location of ODP Site 782 in the Western Pacific Ocean and ODP Site 1007 in the Bahama Bank of Caribbean Sea. 
Site $1007\left(24^{\circ} 30.261^{\prime} \mathrm{N}, 79^{\circ} 19.34^{\prime} \mathrm{W}\right)$ in the Atlantic Ocean (low tropical climates) is located on Bahama Bank of the Caribbean Sea in the Atlantic Ocean, and was obtained from a water depth of $650.3 \mathrm{~m}$ and $647.4 \mathrm{~m}$. At the Caribbean Sea, the main current is the western extension of the North and the South Equatorial current at the Atlantic Ocean.

\section{Materials and Methods}

A total of 234 samples was collected from Hole 782 A and Hole 1007 B, C, covering the middle Miocene to the Pleistocene. The sedimentary section is stratigraphically complete, and is composed of nannnofossil marl and vitric nannofossil chalk at Site 782 [12]. A samples were observed with the studied interval extends from sample 1H-1, 80 - $81 \mathrm{~cm}$ to sample 35X-6, 77 - $76 \mathrm{~cm}$ (2.3 - $332.25 \mathrm{~m}$ below the sea floor: mbsf) of the middle Miocene to Pleistocene.

The sedimentary sequence recovered from ODP Site 1007 (Hole B and C) consists of Pleistocene to upper Oligocene sediments characterized by nannofossil ooze, unlithified to lithified foraminifer and peloidal wackestone and packstone, and foraminifer nannofossil chalk in Hole B and C [13]. The studied interval was between samples 1007B, 23-1, 99 - $100 \mathrm{~cm}$ through 40X-1, 55 - $56 \mathrm{~cm}$ (204.09 - $359.95 \mathrm{mbsf})$, and 1007C, 8R-CC to 50R-CC (378.9 - $783 \mathrm{mbsf}$ ) of the middle Miocene to Pleistocene.

Preparation of the microscope slide explained as follows: samples were dried in oven with temperature around $70^{\circ} \mathrm{C}$ for 24 hour; then by using a mortar, $0.020-0.050 \mathrm{~g}$ (depending on the richness of nannofossil) of powdered were placed in the beaker; and $50 \mathrm{~mL}$ of water were added to make a suspension, stir water to make a suspension; after stirring, the resulted suspension was measured out $0.5 \mathrm{~mL}$ using the micropipettor; to be put carefully and spread over a cover glass $(18 \mathrm{~mm} \times 18 \mathrm{~mm})$ and it was dried on a hotplate at $40^{\circ} \mathrm{C}$; then the cover glass was mounted on a microslide using Norland optical adhesive.

Each microslide was observed under Olympus BX51 binocular polarizing microscope with an oil-immersion objective lens at a magnification of $\times 1500$. We checked all nannofossil species in the microslide to recognize both their first and last occurrence datum planes. Furthermore, we calculate the absolute of coccolith and Discoaster, and relative abundance of each species. The size distribution of Reticulofenestra spp. was also identified by measuring the 50 to 100 of Reticulofenestra specimens in a sample. Absolute ages of datums were provided by Sato and Chiyonobu (in prep.). Reworked of nannofossil species were not documented in any of the samples.

\section{Results}

\subsection{Stratigraphic Distribution of Calcareous Nannofossil and Datums in the Western Pacific and Atlantic Ocean}

We studied the sequence of the middle Miocene to Pleistocene of each Holes. The calcareous nannofossils are generally abundant and preservation is moderate to good in the site 782. However, calcareous nannofossils in site 1007 are moderately to poorly preserve.

\subsubsection{ODP Site 782 Hole A}

The sequence of the Hole is characterized by abundant occurrences of Reticulofenestra spp. The typical cold water species, Coccolithus pelagicus dominate the lower part of the section. Although Calcidiscus leptoporus, and Pontosphaera spp. are very rare, are present throughout the section continuously. The occurrences of Umbilicosphaera sibogae, Syracosphaera pulchra, and Rhabdosphaera clavigera are limited in the upper part of the section (Figure 2).

The nannofossil datum planes and their ages described by Sato and Chiyonobu (in press) and its horizons found in this study, are shown in Table 1. Among them, the datum planes of marker species which define the NN boundaries of Martini's zonation [14], are as follows.

Emiliania huxleyi which defines the NN20/NN21 boundary first occur in sample from 8.4 mbsf. The last occurrence of Pseudoemiliania lacunosa which correlates to NN19/NN20 boundary is found in samples below 18.1 mbsf.

The boundary of NN18/NN19, which is defines by the last occurrence of Discoaster brouweri, is found between 54.6 mbsf/56.1 mbsf. The last occurrences of Discoaster pentaradiatus, D. surculus, Reticulofenestra pseudoumbilicus, and D. quinqueramus, which respectively correlated to NN17/NN18, NN16/NN17, NN15/ 




Figure 2. Stratigraphic distribution of calcareous nannofossil species in ODP Hole 782A located in the Izu Bonin of western Pacific Ocean.

NN16, and NN11/NN12 boundaries are recognized in 67.1 mbsf, 73.6 mbsf, 110.6 mbsf, and 155.85 mbsf. The first occurrences of Discoaster berggrenii and Catinaster coalitus, last occurrences of Cyclicargolithus floridanus and Sphenolithus heteromorphus are respectively found in $234.45 \mathrm{mbsf}, 253.75 \mathrm{mbsf}, 281.05 \mathrm{mbsf}$, and 307.27 mbsf. Based on the stratigraphic position of these species, NN10/NN11, NN7/NN8, NN6/NN7, and NN5/NN6 boundaries are traceable to these horizons mentioned above.

\subsubsection{Hole 1007B, C}

The sequence of this site is correlated to middle Miocene to early Pliocene (Figure 3). The sequence of upper part is characterized by abundant occurrence of Sphenolithus abies which contains $20 \%$ to $50 \%$ of the assemblages. Reticulofenestra spp., which accounts for $30 \%$ to $70 \%$ of the assemblages, dominates the middle to lower part of the sequences (Figure 3). First and last occurrences of the marker species are listed in Table 2.

The zonal boundaries are recognized based on stratigraphic position of the marker species. NN15/NN16 boundary, defined by last occurrence of Reticulofenestra pseudoumbilicus, is found in 205.59 mbsf. Last occurrence of Discoaster quinqueramus which is correlated to NN11/NN12 boundary is found in 286.99 mbsf. The NN10/NN11, NN7/NN8, and NN6/NN7 boundaries defined by first occurrences of Discoaster berggrenii, Catinaster coalitus, and last occurrence of Cyclicargolithus floridanus are recognized in 332.83 mbsf, 504.1 mbsf, and 783 mbsf.

\subsection{Coccolith and Discoaster Productivity, and Reticulofenestra Size Distribution}

\subsubsection{ODP Site 782 Hole A}

Although the mode of Reticulofenestra size is situated around 2 to $3 \mu \mathrm{m}$ throughout the section from middle Miocene to Pleistocene, bimodal peaks occur in some intervals (Figure 4). Larger size mode from 2 to $12 \mu \mathrm{m}$ appear between 13.5 Ma and 8.8 Ma, 8 Ma and 6 Ma, 6 Ma and 3.8 Ma, and above 3 Ma. The larger mode size 
increases in these intervals, and disappear at the top of the intervals.

Relationship between the coccolith productivity and relative abundance of Discoaster shows the negative correlation throughout the section (Figure 4). Coccolith number is low in the section of NN6 and NN7, increases from NN8 to NN16. It also drastically increases the number in the Pleistocene sequence. Relative number of Discoaster which is maximum in NN6 to NN10 in the Miocene, decrease in the sequence above NN10, and abruptly disappeared in 2.0 Ma.

\subsubsection{ODP Site 1007 Hole B and C}

The mode of Reticulofenestra size is situated in 2 to $3 \mu \mathrm{m}$ throughout the section (Figure 5). Bimodal pattern in the sequence also found in the lower part of the section from NN7 to NN10. Another bimodal pattern is also recognized in the lower Pliocene sequence.

Although coccolith productivity increases from NN8 to NN16, relative abundance of Discoaster indicates no significant changes.

\section{Discussion}

\subsection{Global Sea Surface Stability and Significant Paleoceanographic Episodes among the Indian Ocean, Bahama Bank of Caribbean, Northwestern Pacific and Western Pacific Ocean}

We analyze the number of coccolith productivity, Discoaster productivity and size variations of Reticulofenestra

Table 1. Calcareous nannofossil bioevents and ages in Hole 782A (western Pacific Ocean).

\begin{tabular}{|c|c|c|c|}
\hline Calcareous nannofossils event & Age (Ma) & Sample & mbsf \\
\hline FO Emiliania huxleyi & 0.265 & $1 \mathrm{H}-5,90-91 \mathrm{~cm} / 1 \mathrm{H}-6,90-91 \mathrm{~cm}$ & $8.4 / 9.9$ \\
\hline LO Pseudoemiliania lacunosa & 0.451 & $2 \mathrm{H}-4,80-81 \mathrm{~cm} / 2 \mathrm{H}-5,80-81 \mathrm{~cm}$ & $16.6 / 18.1$ \\
\hline FO Gephyrocapsa parallela & 0.987 & $4 \mathrm{H}-1,80-81 \mathrm{~cm} / 4 \mathrm{H}-2,80-81 \mathrm{~cm}$ & 31.1/32.6 \\
\hline LO Helicosphaera sellii & 1.219 & $4 \mathrm{H}-5,80-81 \mathrm{~cm} / 4 \mathrm{H}-6,80-81 \mathrm{~cm}$ & $37.1 / 38.6$ \\
\hline FO Gephyrocapsa spp & 1.392 & $5 \mathrm{H}-1,80-81 \mathrm{~cm} / 5 \mathrm{H}-2,80-81 \mathrm{~cm}$ & $40.6 / 42.1$ \\
\hline FO Gephyrocapsa oceanica & 1.706 & $5 \mathrm{H}-3,80-81 \mathrm{~cm} / 5 \mathrm{H}-4,80-81 \mathrm{~cm}$ & 43.6/45.1 \\
\hline LO Discoaster brouweri & 1.99 & $6 \mathrm{H}-4,80-81 \mathrm{~cm} / 6 \mathrm{H}-5,80-81 \mathrm{~cm}$ & $54.6 / 56.1$ \\
\hline LO Discoaster pentaradiatus & 2.512 & $7 \mathrm{H}-6,80-81 \mathrm{~cm} / 8 \mathrm{H}-1,80-81 \mathrm{~cm}$ & $67.1 / 69.1$ \\
\hline LO Discoaster surculus & 2.52 & $8 \mathrm{H}-4,80-81 \mathrm{~cm} / 8 \mathrm{H}-5,80-81 \mathrm{~cm}$ & $73.6 / 75.1$ \\
\hline LO Discoaster tamalis & 2.87 & $9 \mathrm{X}-1,80-81 \mathrm{~cm} / 9 \mathrm{H}-2,80-81 \mathrm{~cm}$ & $78.6 / 80.1$ \\
\hline LO Sphenolithus abies & 3.65 & $12 \mathrm{X}-1,80-81 \mathrm{~cm} / 12 \mathrm{X}-2,80-81 \mathrm{~cm}$ & 107.6/109.1 \\
\hline LO Reticulofenestra pseudoumbilicus & 3.79 & $12 X-3,80-81 \mathrm{~cm} / 13 \mathrm{X}-1,80-81 \mathrm{~cm}$ & 110.6/117.3 \\
\hline FO Discoaster tamalis & 4 & $13 X-1,80-81 \mathrm{~cm} / 13 X-2,80-81 \mathrm{~cm}$ & $117.3 / 118.8$ \\
\hline FO Pseudoemiliania lacunosa & 4 & $13 \mathrm{X}-1,80-81 \mathrm{~cm} / 13 \mathrm{X}-2,80-81 \mathrm{~cm}$ & 117.3/118.8 \\
\hline FO Discoaster asymmetricus & 4.13 & $15 X-1,80-81 \mathrm{~cm} / 15 \mathrm{X}-2,80-81 \mathrm{~cm}$ & 136.6/138.1 \\
\hline LO Discoaster quinqueramus & 5.59 & $17 \mathrm{X}-1,75-76 \mathrm{~cm} / 17 \mathrm{X}-2,74-75 \mathrm{~cm}$ & $155.85 / 157.34$ \\
\hline LO Discoaster berggrenii & 5.59 & $17 \mathrm{X}-1,75-76 \mathrm{~cm} / 17 \mathrm{X}-2,74-75 \mathrm{~cm}$ & $155.85 / 157.34$ \\
\hline FO Amaurolithus spp & 7.424 & $17 \mathrm{X}-1,75-76 \mathrm{~cm} / 17 \mathrm{X}-2,74-75 \mathrm{~cm}$ & $155.85 / 157.34$ \\
\hline FO Discoaster berggrenii & 8.52 & $25 X-1,75-76 \mathrm{~cm} / 25 X-2,75-76 \mathrm{~cm}$ & $232.95 / 234.45$ \\
\hline Bottom of small Reticulofenestra interval & 8.761 & $25 X-4,75-76 \mathrm{~cm} / 25 X-5,75-76 \mathrm{~cm}$ & $237.45 / 238.95$ \\
\hline LO Catinaster coalitus & 9.674 & $26 \mathrm{X}-3,75-76 \mathrm{~cm} / 26 \mathrm{X}-4,75-76 \mathrm{~cm}$ & $245.55 / 247.05$ \\
\hline LO Coccolithus miopelagicus & 10.613 & $26 \mathrm{X}-5,75-76 \mathrm{~cm} / 26 \mathrm{X}-6,75-76 \mathrm{~cm}$ & $248.55 / 250.05$ \\
\hline FO Catinaster coalitus & 10.785 & $27 \mathrm{X}-1,75-76 \mathrm{~cm} / 27 \mathrm{X}-2,75-76 \mathrm{~cm}$ & $252.25 / 253.75$ \\
\hline LO Coronocyclus nitescens & 12.254 & $28 X-6,75-76 \mathrm{~cm} / 29 \mathrm{X}-1,75-76 \mathrm{~cm}$ & $269.35 / 271.45$ \\
\hline LO Cyclicargolithus floridanus & 13.294 & 29-X6, $75-76 \mathrm{~cm} / 30 \mathrm{X}-1,75-76 \mathrm{~cm}$ & $278.95 / 281.05$ \\
\hline LO Sphenolithus heteromorphus & 13.654 & $33 X-1,75-76 \mathrm{~cm} / 33 \mathrm{X}-2,77-78 \mathrm{~cm}$ & $305.75 / 307.27$ \\
\hline
\end{tabular}

FO: first occurrence; LO: last occurrence. 


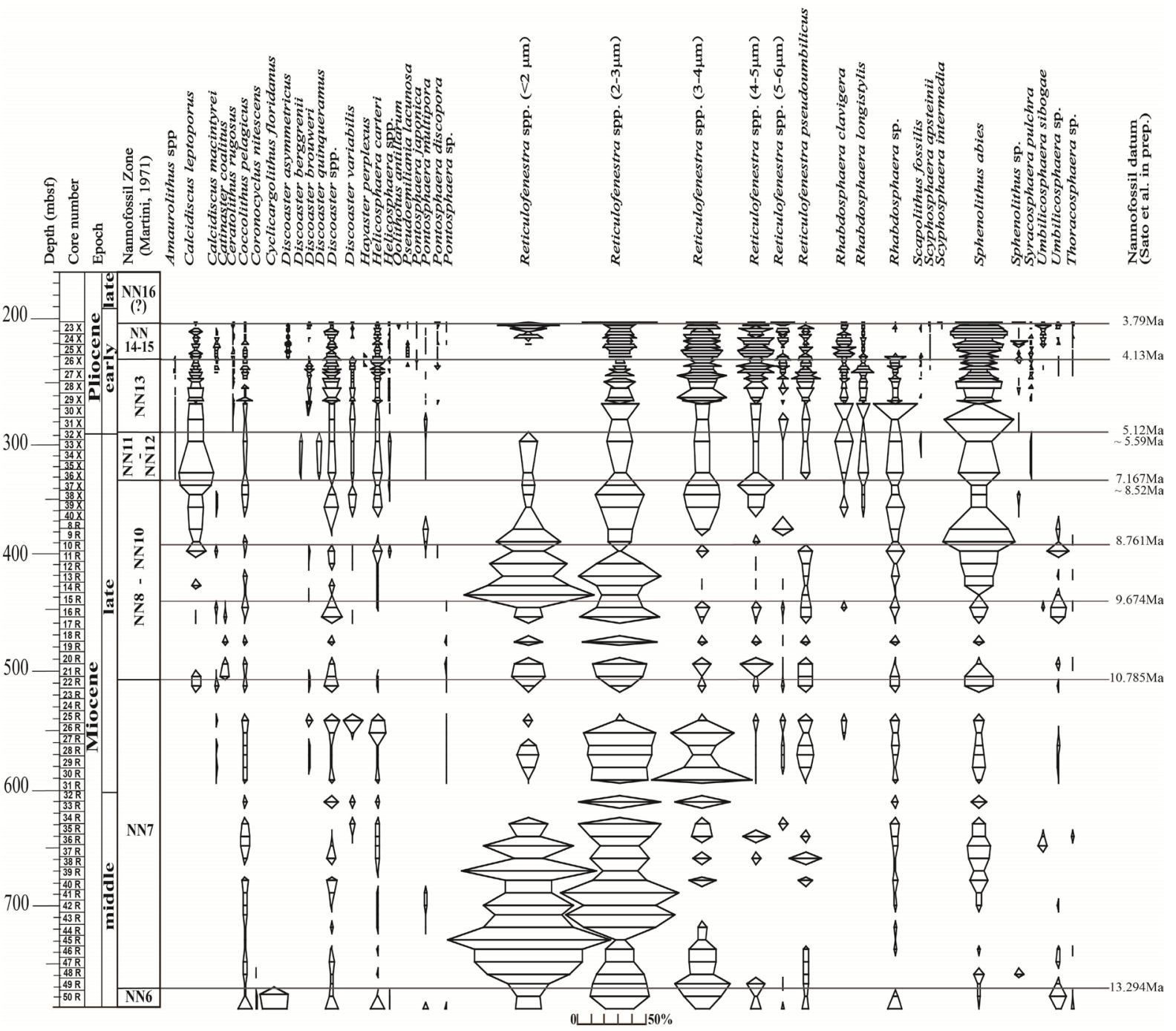

Figure 3. Stratigraphic distribution of calcareous nannofossil species in ODP Site 1007 situated in Bahama Bank of the Caribbean Sea in the Atlantic Ocean.

Table 2. Calcareous nannofossil bioevents and ages in Hole 1007B and 1007C (Bahama Bank of Caribbean Sea).

\begin{tabular}{|c|c|c|c|}
\hline Calcareous nannofossils event & Age (Ma) & Sample & mbsf \\
\hline LO Reticulofenestra pseudoumbilicus & 3.79 & 1007B-23X-2, 99 - 100 cm/23X-3, $99-100 \mathrm{~cm}$ & $205.59 / 207.09$ \\
\hline FO Discoaster asymmetricus & 4.13 & 26X-1, $99-100 \mathrm{~cm} / 26 \mathrm{X}-2,99-100 \mathrm{~cm}$ & $231.59 / 233.09$ \\
\hline FO Ceratolithus rugosus & 5.12 & $32 X-1,99-100$ cm/34X-1, $99-100 \mathrm{~cm}$ & 286.99/305.3 \\
\hline LO Discoaster quinqueramus & 5.59 & $32 X-1,99-100$ cm/34X-1, $99-100 \mathrm{~cm}$ & 286.99/305.3 \\
\hline LO Discoaster berggrenii & 5.59 & $32 X-1,99-100 \mathrm{~cm} / 34 X-1,99-100 \mathrm{~cm}$ & 286.99/305.3 \\
\hline Top of small Reticulofenestra interval & 7.167 & $37 X-1,99-100$ cm/38X-1, $99-100 \mathrm{~cm}$ & $332.82 / 342.09$ \\
\hline FO Discoaster berggrenii & 8.52 & $37 \mathrm{X}-1,99-100 \mathrm{~cm} / 38 \mathrm{X}-1,99-100 \mathrm{~cm}$ & $332.82 / 342.09$ \\
\hline Bottom of small Reticulofenestra interval & 8.761 & 1007C-9R-CC/10R-CC & $388.5 / 398.1$ \\
\hline LO Catinaster coalitus & 9.674 & 15R-CC/16R-CC & 446.3/455.9 \\
\hline FO Catinaster coalitus & 10.785 & 21R-CC/22R-CC & $504.1 / 513.7$ \\
\hline LO Cyclicargolithus floridanus & 13.294 & 49R-CC/50R-CC & 773.3/783 \\
\hline
\end{tabular}

FO: first occurrence; LO: last occurrence. 


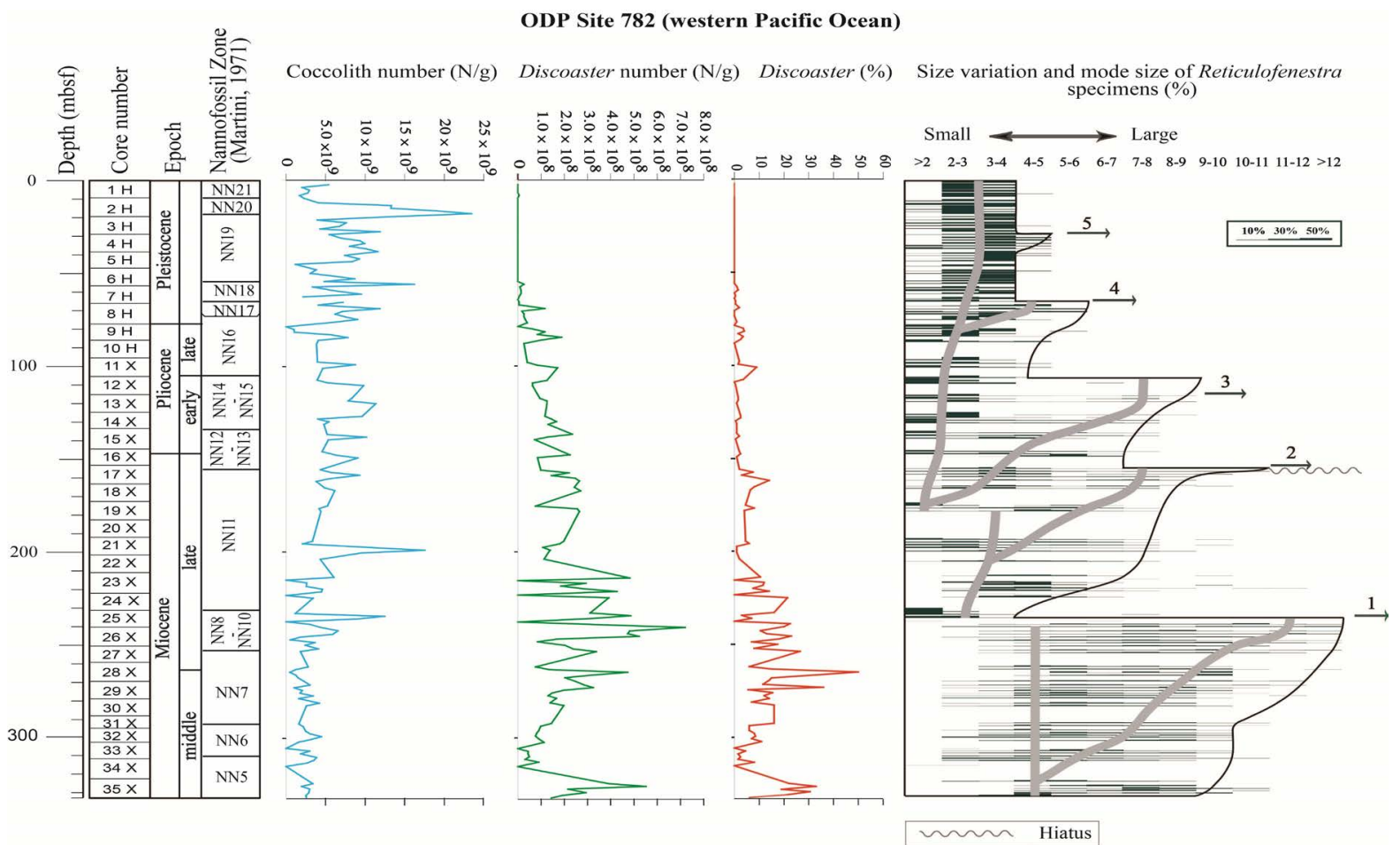

Figure 4. A comparison of coccolith number (N/g), Discoaster productivity, percentage of Discoaster, and mode size variation of Reticulofenestra, in ODP Hole 782A.

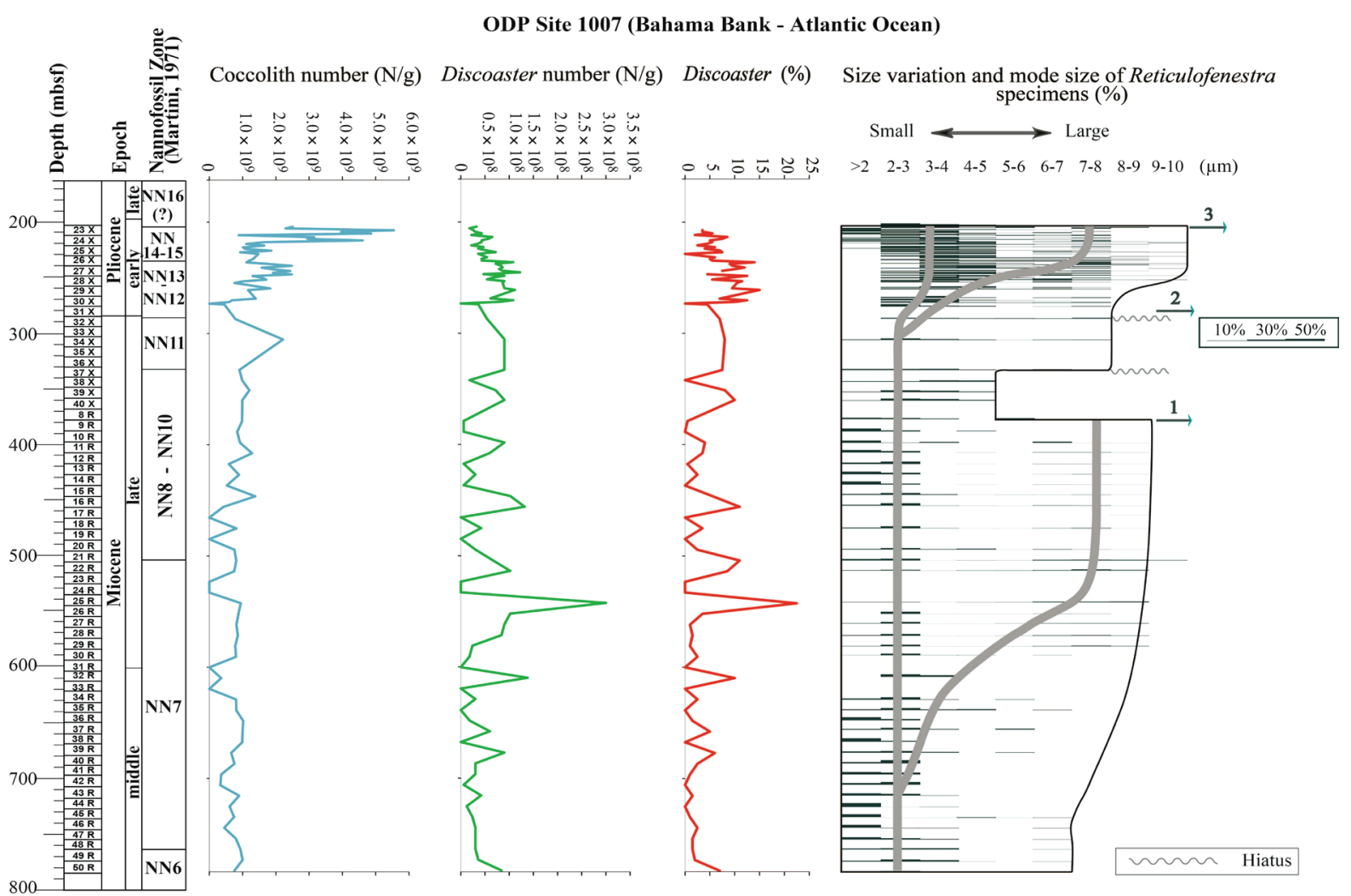

Figure 5. A comparison of coccolith number (N/g), Discoaster productivity, percentage of Discoaster, and mode size variation of Reticulofenestra, in ODP Site 1007. 
to reconstruct the Neogene paleoceanography of Bahama Bank of Atlantic and western Pacific Ocean (Figure 6, Figure 7).

The coccolith productivity of site 782 is characterized by increasing from NN6 to lower part of NN8-NN10 Zone while the relative abundant of Discoaster species shows opposite trends in this interval. The mode and maximum size of the Reticulofenestra show five times increasing patterns while the mode indicates bimodal (Figure 6). The general patterns of maximum of Reticulofenestra are indicated by decreasing in this sequence from 14 Ma to recent. The change in relative abundance and productivity of coccolith are also closely related with the stepwise change in the modal size of Reticulofenestra in NN10, NN11, NN17 and NN19 Zone (Figure 6).

Although the coccolith and Discoaster productivity of Site 1007 located in the Bahama Bank is not changed clearly during Miocene sequence, coccolith productivity suddenly increased in the early Pliocene of NN12 to NN16 (Figure 7). The mode and maximum size of the Reticulofenestra show two times increasing patterns while the mode indicates bimodal (Figure 7). The dominance of small Reticulofenestra in 8.8 Ma are positive correlation with coccolith productivity.

Figure 8 shows the correlation of coccolith number, relative abundance of Discoasters, and maximum size of Reticulofenestra between sites 782 and 1007. The drastically decreasing of maximum size of Reticulofenestra at 8.8 Ma in the late middle Miocene and 3.75 Ma in the late early Pliocene is found in both sites.

Focusing to paleoceanography analysis, nannofossil has been described as a good tool for reconstruct the oceanographic condition. Molfino and McIntyre [2] described the utility of Florisphaera profunda assemblages which shows the stability of sea surface condition. However, as Florisphaera profunda first appears in late Neogene, it's impossible to analyze the Neogene paleoceanographic conditions based on Florisphaera profunda assemblages. Recently, Sato and Chiyonobu [8] focused to Discoasters for paleoceanographical analysis. Discoasters had been believed the warm water species based on distributions in low latitude region [15]-[17]. However, Aubry [5], Chepstow-Lusty [18], Stoll et al. [6], and Sato and Chiyonobu [8] described that Discoasters lived in lower photic zone of oligotrophic environment and its ecology is similar to Florisphaera profunda.

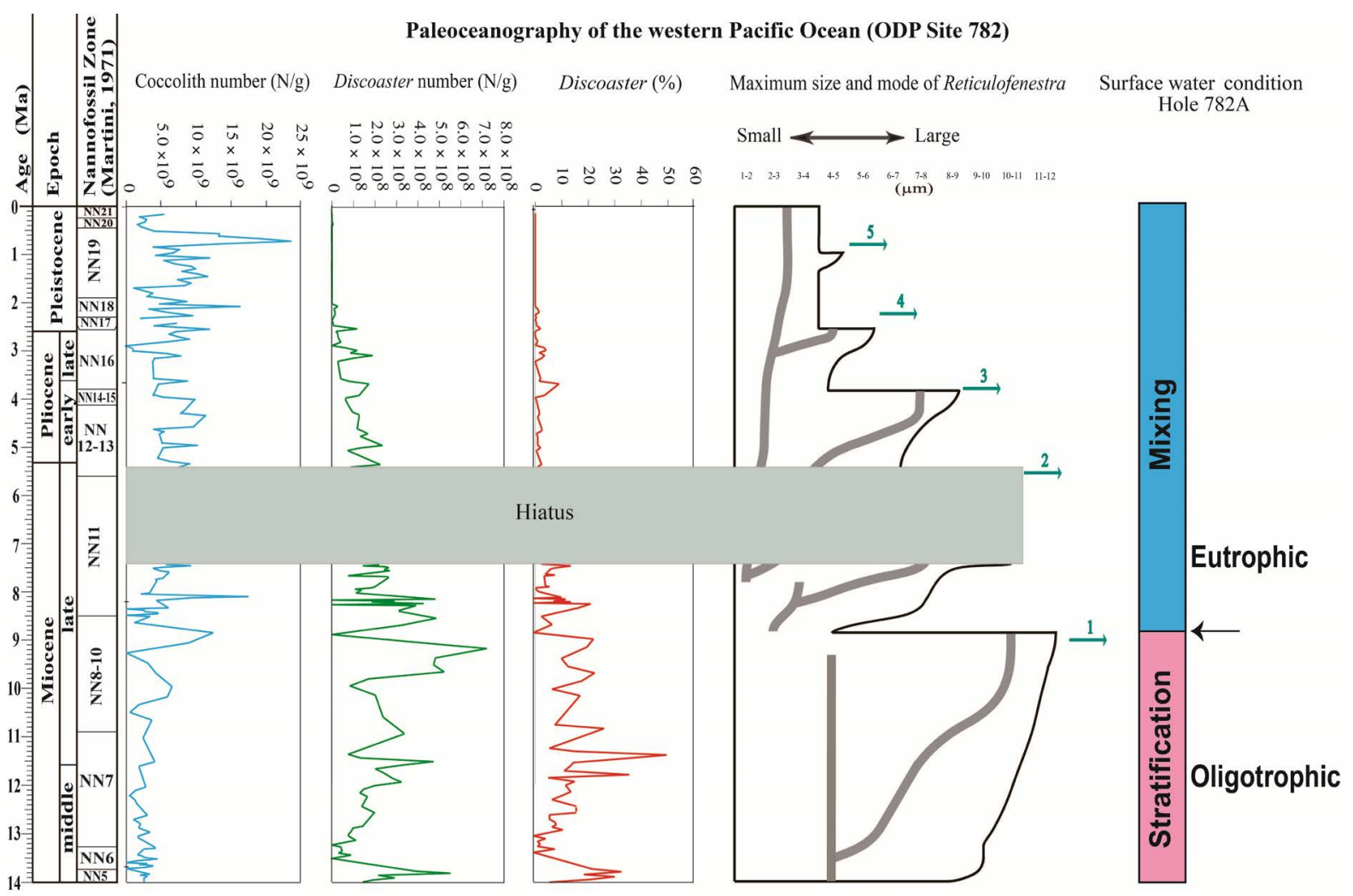

Figure 6. A summary correlation between coccolith number (N/g), Discoaster productivity, percentages of Discoaster, and size distribution of Reticulofenestra, with changes of surface water condition in ODP Hole 782A. 


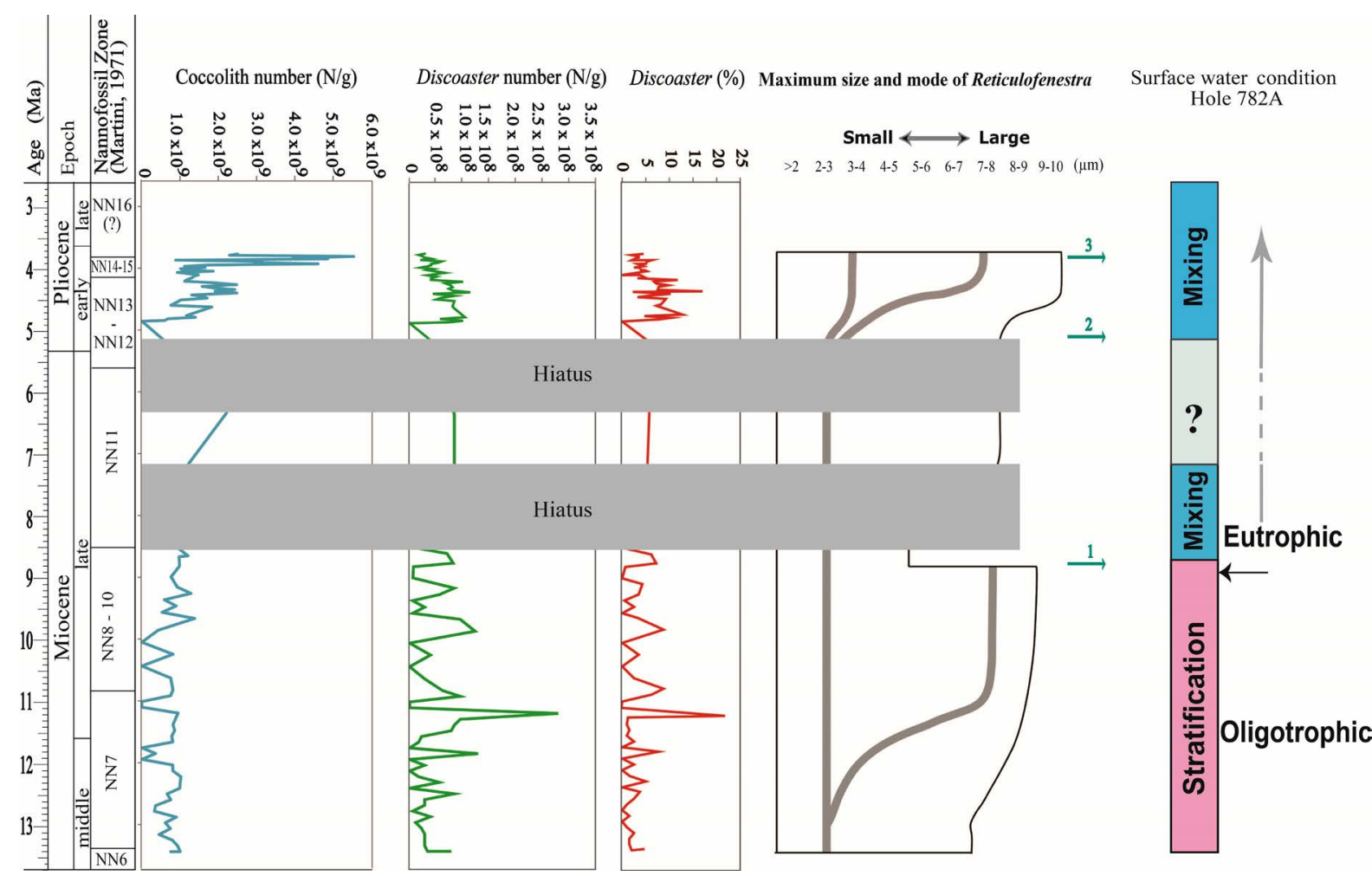

Figure 7. A summary correlation between coccolith numbers (N/g), Discoaster productivity, percentage of Discoaster, and size distribution of Reticulofenestra, with changes of surface water condition in ODP Site 1007.

This means that abundant occurrence of Discoaster indicates the distribution of stable sea surface condition with thermocline and nutricline.

On the other hand, distinct size variations of Reticulofenestra in the Miocene sequence are reported by many authors [8]-[11] [19]-[22]. Hagino et al. (2000) suggested that small specimens of Reticulofenestra were more abundant in eutrophic surface waters than in oligotrophic surface waters [23]. Recently, Sato and Chiyonobu (2009) studied the size variations of Reticulofenestra in the middle Miocene sequence in Pacific Ocean, and described that the presence of large size Reticulofenestra shows the stable and oligotrophic sea surface condition [8]. On the basis of the these phenomena, Farida et al. (2012) suggested that the collapse of thermo- and nutri-cline occurs step by step during Miocene to Quaternary at ODP Hole 805B in the western equatorial Pacific Ocean based on Discoaster relative abundance and the Reticulofenestra size variations [9]. These studies also indicated that the collapse of the stability of the sea surface stratification in the equatorial western Pacific Ocean has been changed in steps by steps from oligotrophic to eutrophic conditions during the Miocene to Quaternary.

Based on these results, we interpret the paleoceanographic environment in the study area. The maximum size of Reticulofenestra increased until 8.8 Ma which shows the oligotrophic conditions with sea surface stratification and thermocline. However, the maximum size of Reticulofenestra suddenly decreased at 8.8 Ma, 5.4 Ma, 3.75 Ma and 2.516 Ma. This means that the stabilization of the Ocean condition in the western Pacific Ocean collapse at 8.8 Ma, 5.4 Ma, 3.75 Ma and 2.516 Ma as a result of change to eutrophic sea surface conditions (Figure 8).

We also make comparison between our results and those studied previously in the Indian Ocean (Young, 1990) [11] and in the northwestern Pacific Ocean (Imai et al., 2015) [10]. Young [11] present three bimodalization occurred in the Indian Ocean sites from NN6 to NN16 Zone at 8.8 Ma; 5.4 Ma; and 3.75 Ma (Figure 9). The strong decreased maximum size of Reticulofenestra coccoliths is present in 8.8 Ma. These events are responsible for the change of sea surface stability in the Indian Ocean. Imai et al. [10] studied calcareous nannofossil assemblages from ODP holes 1210A in the northwestern Pacific Ocean also present the large number of Reticulofenestra coccolith indicates a shallow thermo- and nutricline is drastically change to the small size in six times (in 8.8 Ma, 6.4 Ma, 5.4 Ma, 3.75 Ma, 3.4 Ma and 2.75 Ma) in this sites. Figure 9 shows the changes of mode 


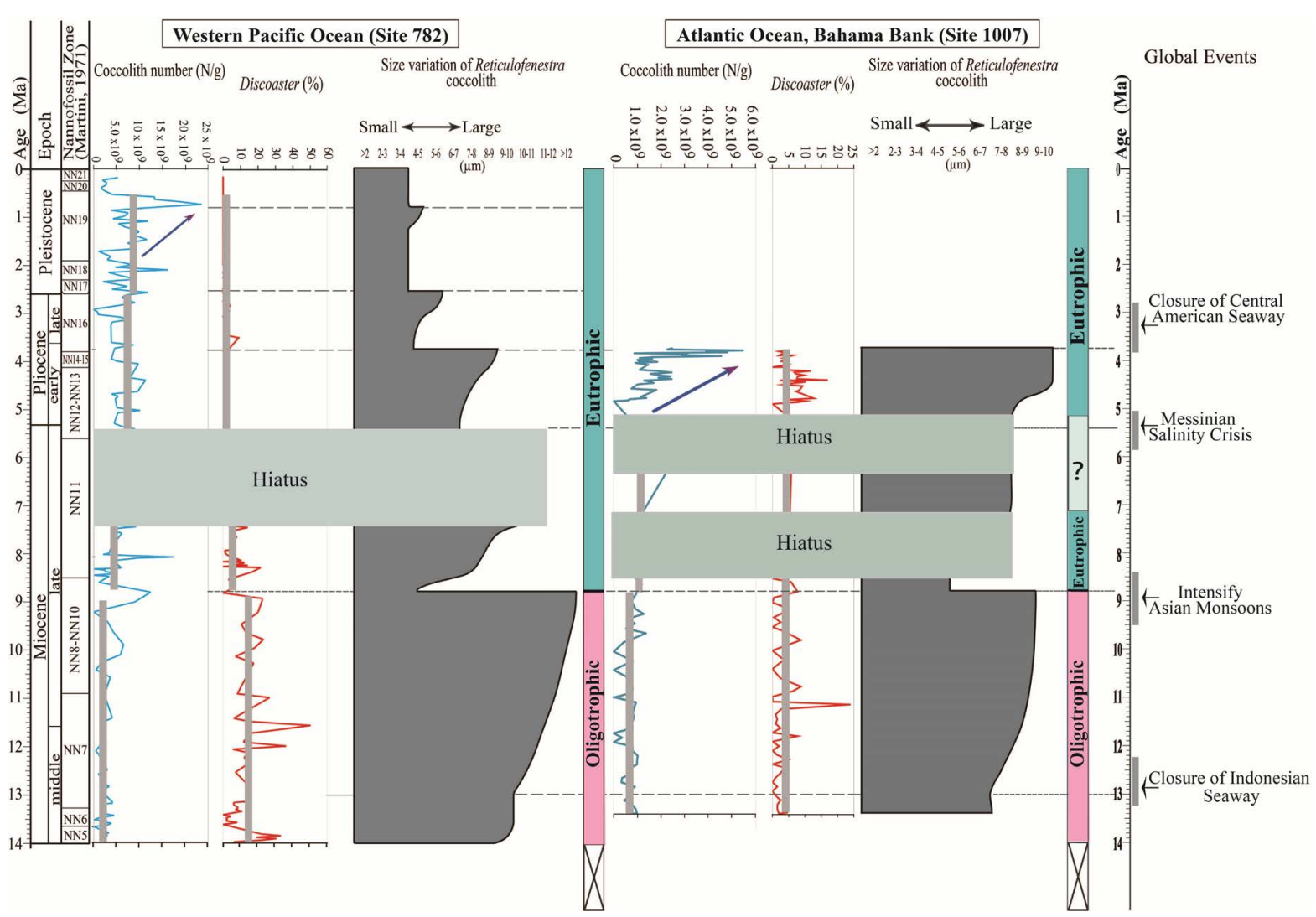

Figure 8. A correlation between Paleoceanography conditions based on calcareous nannofossil assemblages throughout the middle Miocene to Pleistocene sections in western Pacific Ocean (Site 782), and Bahama Bank of Atlantic Ocean (Site 1007) and Global climate events.

size of Reticulofenestra. This indicates that the mode size decreased four times throughout the sequence in 8.8 Ma, 6.4 Ma, 5.4 Ma and in 3.75 Ma (1, 2, 3, 4 in Figure 9). Furthermore, these events are also traceable to the western Pacific, Bahama Bank, Indian Ocean and to the northwestern Pacific Ocean. This means that the sea surface stability of the world ocean was collapsed four times during Neogene time. Furthermore, compared with other sites, northwestern Pacific Ocean is also characterized by the strong eutrophication in 8.8 Ma, 6.4 Ma, 5.4 Ma and at 3.75 Ma based on size variations.

These results indicate that nannofossil events recognized in this study show the drastic changes of paleoceanography in the world occurred four times throughout the Neogene. Especially the events are distinct in the Pacific Ocean.

\subsection{Correlation of the Global Tectonic Events and Paleoceanography of the Western Pacific and Bahama Bank of Atlantic Ocean}

Many global tectonic and climatic events occurred in the Neogene have been studied. We compare the present investigated results of the size variation of Reticulofenestra in the western Pacific Ocean and Caribbean sea with those in Indian Ocean [11] and northwestern Pacific [10] (Figure 9). Changes of Reticulofenestra maximum and mode size which are strongly related to the collapse of stability of Ocean surface are clearly traceable to these oceans. Among these events, two of them are found in the oceans distinctly. These are as follows:

Event (1): Found in the uppermost NN10 Zone in the late Miocene (8.8 Ma; Figure 9)

Event (4): Found in the NN15/NN16 boundary in the Pliocene (3.75 Ma; Figure 9)

The changes of maximum size of Reticulofenestra are strongly influenced by collapse of sea surface stability related to disappearance of nutricline by upwelling. Based on the characteristics on relation between size variability and nutrient condition, these nannofossil events are interpreted as change to high nutrient condition resulted in the changes of Global climate system. During $8 \mathrm{Ma}$ and $10 \mathrm{Ma}$ is characterized by the intensify the 


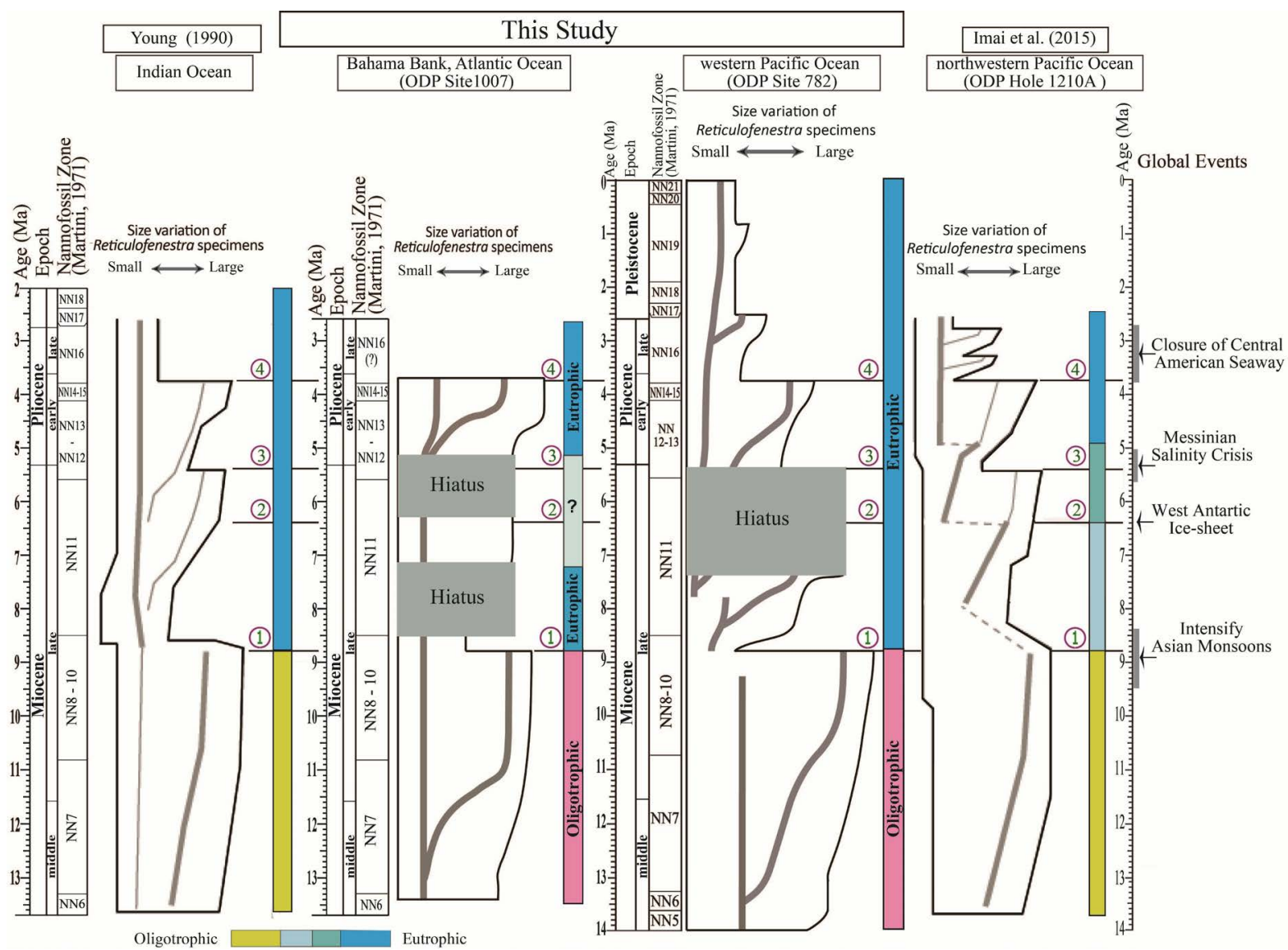

Figure 9. A summary of Reticulofenestra coccoliths size distribution in the Indian Ocean, Bahama Bank of Atlantic, northwestern Pacific and the western Pacific Ocean, with interpretation in the paleoceanography condition.

Asian Monsoon caused by uplift of Tibetan Plateau [24]-[27]. This means that Event (1) recognized in 8.8 Ma in the Indian Ocean, Bahama Bank of Atlantic Ocean, and western Pacific Ocean are strongly influenced by the intensify the Asian Monsoon.

Event (4) of 3.75 Ma is strongly related to formation of Panama Isthmus. Haug and Tiedman [28] described that current system across the Panama Seaway was changed from 4.6 Ma and intensification of northern hemisphere glaciation was pronounced between 3.1 Ma and 2.5 Ma. Kameo and Sato [21], Sato et al. [29], and Bartoli et al. [30] also described the final closure of Panama Isthmus was established around 2.75 Ma based on nannofossil assemblages and isotope stratigraphy. On the basis of these facts, drastic decrease of maximum size of Reticulofenestra occurred in 3.75 Ma was strongly influenced by closure of Panama Isthmus.

The additional events (2) and (3) in Figure 9 found in northwestern Pacific and Indian Ocean (Figure 9) which are indicated by maximum size changes of Reticulofenestra, is correlated to the formation of hiatus in the western Pacific Ocean and Bahama Bank (Figure 9). These two events are correlated to 6.4 Ma and 5.4 Ma. The ages of these events are also respectively correlated to global events as formation of western Antarctic ice sheet and Messinian salinity crisis. Krijgsman et al. [31] presented astronomically calibrated chronology for the Messinian salinity crisis. They show that the onset of the Messinian salinity crisis at $5.96 \pm 0.02 \mathrm{Ma}$ and also isolation from the Atlantic Ocean was established between 5.59 and 5.33 Ma. Messinian salinity crisis event influenced to changes of sea surface stability conditions in the global sea level [32] [33]. This indicates that the event (3) in 5.4 Ma indicated by size changes of Reticulofenestra, is strongly influenced by Messinian Salinity Crisis.

\section{Conclusions}

The distribution of coccolith abundance, Discoaster productivity and Reticulofenestra species size through the Neogene sequences in western Pacific and Bahama Bank was studied to reconstruct the ocean surface stability. 
Our results indicated that the size of Reticulofenestra increased five times throughout the section. However, it drastically decreased in NN8-10 (8.8 Ma), NN12-13 (5.4 Ma), NN14-NN15 (3.75 Ma), NN17/NN18 (2.514 Ma) and in NN19 Zone (0.8 Ma) in the western Pacific site. These changes of Reticulofenestra maximum size which are strongly related to the collapse of stability of Ocean surface are clearly traceable to Bahama Bank, western and northwestern Pacific Ocean and Indian Ocean.

Among them, two events found in 8.8 Ma and 3.75 Ma are respectively correlated to intensify the Asian Monsoon and closure of Panama Isthmus. These results indicate that the collapse of sea surface stability in 8.8 Ma is strongly influenced by intensifying the Asian Monsoon, and that in 3.75 Ma was influenced by closuring the Panama Isthmus.

\section{Acknowledgements}

Sample for this study were provided by the Ocean Drilling Program. The authors are thanks to Leading Program Grant Akita University for supporting this work.

\section{References}

[1] Okada, H. and Honjo, S. (1973) The Distribution of Oceanic Coccolithophores in the Pacific. Deep Sea Research, 20, 355-374.

[2] Molfino, B. and Mcintyre, A. (1990) Precession Forcing of Nutricline Dynamics in the Equatorial Atlantic. Science, 249, 766-769. http://dx.doi.org/10.1126/science.249.4970.766

[3] Haq, B.U. and Lohmann, G.P. (1976) Early Cenozoic Calcareous Nannoplankton Biogeography of the Atlantic Ocean. Marine Micropaleontology, 1, 119-120. http://dx.doi.org/10.1016/0377-8398(76)90008-6

[4] Bukry, D. (1978) Biostratigraphy of Cenozoic Marine Sediment by Calcareous Nannofossils. Micropaleontology, 24, 44-60. http://dx.doi.org/10.2307/1485419

[5] Aubry, M.P. (1992) Late Paleogene Calcareous Nannoplankton Evolution: A Tale of Climatic Deterioration. In: Prothero, D.R., Berggren, W.A., Eds., Eocene-Oligocene Climatic and Biotic Evolution, Princeton University Press, Princeton, NJ, 272-309. http://dx.doi.org/10.1515/9781400862924.272

[6] Stoll, H.M., Shimizu, N., Archer, D. and Ziveri, P. (2007) Coccolithophore Productivity Response to Greenhouse Event of the Paleocene-Eocene Thermal Maximum. Earth and Planetary Sciences Letters, 258, 192-206. http://dx.doi.org/10.1016/j.epsl.2007.03.037

[7] Takahashi, K. and Okada, H. (2000) The Paleoceanography for the Last 30,000 Years in the Southeastern Indian Ocean by Means of Calcareous Nannofossils. Marine Micropaleontology, 40, 83-103. http://dx.doi.org/10.1016/S0377-8398(00)00033-5

[8] Sato, T. and Chiyonobu, S. (2009) Cenozoic Paleoceanography Indicated by Size Change of Calcareous Nannofossil and Discoaster Number. Fossils (Palaeontological Society of Japan), 86, 12-19. (In Japanese with English Abstract)

[9] Farida, M., Imai, R. and Sato, T. (2012) Miocene to Pliocene Paleoceanography of the Western Equatorial Pacific Ocean Based on Calcareous Nannofossils, ODP Hole 805B. Open Journal of Geology, 2, 72-79. http://dx.doi.org/10.4236/ojg.2012.22008

[10] Imai, R., Farida, M. and Iryu, Y. (2015) Evidence for Eutrophication in the Northwestern Pacific and Eastern Indian Oceans during the Miocene to Pleistocene Based on the Nannofossil Accumulation Rate, Discoaster Abundance, and Coccolith Size Distribution of Reticulofenestra. Marine Micropaleontology, 116, 15-27. http://dx.doi.org/10.1016/j.marmicro.2015.01.001

[11] Young, J.R. (1990) Size Variation of Neogene Reticulofenestra Coccoliths from Indian Ocean DSDP Cores. Journal of Micropaleontology, 9, 71-86. http://dx.doi.org/10.1144/jm.9.1.71

[12] Shipboard Scientific Party (1990) Site 782. In: Fryer, P., Pearce, J.A., Stokking, L.B., et al., Eds., Proceedings of the Ocean Drilling Program, Initial Reports 125, College Station, Texas, 197-252. http://dx.doi.org/10.2973/odp.proc.ir.125.110.1990

[13] Shipboard Scientific Party (1997) Site 1007. In: Eberli, G.P., Swart, P.K., Malone, M.J., et al., Eds., Proceedings of the Ocean Drilling Program, Initial Reports 166, College Station, Texas, 289-345. http://dx.doi.org/10.2973/odp.proc.ir.166.110.1997

[14] Martini, E. (1971) Standard Tertiary and Quaternary Calcareous Nannoplankton Zonation. In: Farinacci, A., Ed., Proceedings of the Second Planktonic Conference, Roma, 1970, 739-785.

[15] Haq, B.U. (1980) Biogeographic History of Miocene Calcareous Nannoplankton and Paleoceanography of the Atlantic Ocean. Micropaleontology, 26, 414-443. http://dx.doi.org/10.2307/1485353 
[16] Bukry, D. (1971) Discoaster Evolutionary Trends. Micropaleontology, 17, 43-52. http://dx.doi.org/10.2307/1485036

[17] Bukry, D. (1973) Coccolith and Silicoflagellate Stratigraphy, Tasman Sea and Southwestern Pacific Ocean, Deep Sea Drilling Project Leg 21. In: Burns, R.E., Andrew, J.E., et al., Eds., Initial Reports of the Deep Sea Drilling Project 21, US Government Printing Office, Washington, 885-893. http://dx.doi.org/10.2973/dsdp.proc.21.127.1973

[18] Chepstow-Lusty, A., Backman, J. and Shackleton, N.J. (1989) Comparison of Upper Pliocene Discoaster Number Variations from North Atlantic Sites 552, 607, 658, 659, and 662: Further Evidence for Marine Plankton Responding to Orbital Forcing. Proceedings of the Ocean Drilling Program, Scientific Results 108, College Station, Texas, 121141.

[19] Pujos, A. (1987) Late Eocene to Pleistocene Medium-Sized and Small-Sized “Reticulofenestrids”. Abhandlungen der Geologischen Bundesanstalt, 39, 239-277.

[20] Kameo, K. and Takayama, T. (1999) Biostratigraphic Significance of Sequential Size Variations of the Calcareous Nannofossil Genus Reticulofenestra in the Upper Pliocene of the North Atlantic. Marine Micropaleontology, 37, 4152. http://dx.doi.org/10.1016/S0377-8398(99)00009-2

[21] Kameo, K. and Sato, T. (2000) Biogeography of Neogene Calcareous Nannofossils in the Caribbean and the Eastern Equatorial Pacific- Floral Response to the Emergence of the Isthmus of Panama. Marine Micropaleontology, 39, 201218. http://dx.doi.org/10.1016/S0377-8398(00)00021-9

[22] Chiyonobu, S., Sato, T., Narikiyo, R. and Yamasaki, M. (2006) Floral Changes in Calcareous Nannofossils and Their Paleoceanographic Significance in the Equatorial Pacific Ocean during the Last 500000 Years. Island Arc, 15, 476-482. http://dx.doi.org/10.1111/j.1440-1738.2006.00543.x

[23] Hagino K., Okada H. and Matsuoka H. (2000) Spatial Dynamics of Coccolithophore Assemblages in the Equatorial Western-Central Pacific Ocean. Marine Micropaleontology, 39, 53-72. http://dx.doi.org/10.1016/S0377-8398(00)00014-1

[24] Burbank, D.W., Derry, L.A. and France-Lanord, C. (1993) Reduced Himalayan Sediment Production 8 Myr Ago Despite an Intensified Monsoon. Nature, 364, 48-54. http://dx.doi.org/10.1038/364048a0

[25] Filippelli, G.M. (1997) Intensification of the Asian Monsoon and a Chemical Weathering Event in the Late Miocene-Early Pliocene: Implications for Late Neogene Climate Change. Article in Geology, 25, 27-30. http://dx.doi.org/10.1130/0091-7613(1997)025<0027:IOTAMA>2.3.CO;2

[26] Zhisheng, A., Kutzbach, J.E., Prell, W.L. and Porter, S.C. (2001) Evolution of Asian Monsoons and Phased Uplift of the Himalaya-Tibetan Plateau since Late Miocene Times. Nature, 411, 62-66. http://dx.doi.org/10.1038/35075035

[27] Zachos, J., Pagani, M., Sloan, L., Thomas, E. and Billups, K. (2001) Trends, Rhythms, and Aberrations in Global Climate 65 Ma to Present. Science, 292, 686-693. http://dx.doi.org/10.1126/science.1059412

[28] Haug, G.H. and Tiedemann, R. (1998) Effect of the Formation of the Isthmus of Panama on Atlantic Ocean Thermohaline Circulation. Nature, 393, 673-676. http://dx.doi.org/10.1038/31447

[29] Sato, T., Yuguchi, S., Takayama, T. and Kameo, K. (2004) Drastic Change in the Geographical Distribution of the Cold-Water Nannofossil Coccolithus pelagicus (Wallich) Schiller at 2.74 Ma in the Late Pliocene, with Special Reference to Glaciation in the Arctic Ocean. Marine Micropaleontology, 52, 181-193. http://dx.doi.org/10.1016/j.marmicro.2004.05.003

[30] Bartoli, G., Sarnthein, M., Weinelt, M., Erlenkeuser, H., Garbe-Schonberg, D. and Lea, D.W. (2005) Final Closure of Panama and the Onset of Northern Hemisphere Glaciation. Earth and Planetary Science Letters, 237, 33-44. http://dx.doi.org/10.1016/j.epsl.2005.06.020

[31] Krijgsman, W., Hilgen, F., Raffi, I., Sierro, F. and Wilson, D. (1999) Chronology, Causes and Progression of the Messinian Salinity Crisis. Nature, 400, 652-655. http://dx.doi.org/10.1038/23231

[32] Hodell, D.A., Kanfoush, S.L., Shemesh, A., Crosta, X., Charles, C.D. and Guilderson, T.P. (2001) Abrupt Cooling of Antarctic Surface Waters and Sea Ice Expansion in the South Atlantic Sector of the Southern Ocean at 5000 cal yr B. P. Quaternary Research, 56, 191-198. http://dx.doi.org/10.1006/qres.2001.2252

[33] Warny, S.A., Bart, P.J. and Suc, J.-P. (2003) Timing and Progression of Climatic, Tectonic and Glacioeustatic Influences on the Messinian Salinity Crisis. Palaeogeography, Palaeoclimatology, Palaeoecology, 202, 59-66.

http://dx.doi.org/10.1016/S0031-0182(03)00615-1 


\section{Submit or recommend next manuscript to SCIRP and we will provide best service for you:}

Accepting pre-submission inquiries through Email, Facebook, LinkedIn, Twitter, etc.

A wide selection of journals (inclusive of 9 subjects, more than 200 journals)

Providing 24-hour high-quality service

User-friendly online submission system

Fair and swift peer-review system

Efficient typesetting and proofreading procedure

Display of the result of downloads and visits, as well as the number of cited articles

Maximum dissemination of your research work

Submit your manuscript at: http://papersubmission.scirp.org/ 